\title{
PENGENDALIAN ALIH FUNGSI LAHAN PERTANIAN PANGAN BERKELANJUTAN
}

\author{
Komang Triana Ayunita, Ida Ayu Putu Widiati, I Nyoman Sutama \\ Fakultas Hukum Universitas Warmadewa, Denpasar-Bali, Indonesia
}

\begin{abstract}
Abstrak
Indonesia merupakan negara yang terdiri dari beberapa pulau dengan keindahan alam yang tiada tara. Salah satu pesona alam di Indonesia adalah area hijau yaitu sawah. Tempat yang digemari turis mengabadikan foto mereka yang kagum akan pesona persawahan, namun semakin hari semakin terkikis oleh jaman dimana sawah kini beralih fungsi dari kawasan hijau menjadi kawasan pabrik, perumahan, toko dan swalayan. Keinginan setiap individu yang semakin hari ingin semakin sukses namun melupakan betapa pentingnya kawasa hijau, sehingga pemerintah menetapkan peraturan pembatasan seseorang untuk alih fungsi lahan sawah, dan sanksi bagi seseorang yang secara sengaja melanggar aturan pemerintah. Penelitian ini bertujuan untuk menjelaskan pengaturan alih fungsi lahan pertanian pangan berkelanjutan dan menjelaskan upaya pemerintah dalam pengendalian alih fungsi lahan pertanian pangan berkelanjutan. Penelitian ini menggunakan Penelitian hukum normatif adalah hukum kepustakaan yang mengacu pada norma hukum yang terdapat dalam peraturan Perundang-undangan dengan pendekatan perundan-undangan. Sumber data adalah data hukum primer dan sekunder. Hasil penelitian menunjukkan bahwa Aturan pemerintah tidak dapat terealisasi secara merata tanpa ada kesadaran dari masyarakat itu sendiri, bersama-sama menerapkan sikap tertib hukum yang membuat pemerintah dapat menata kembali kawasan hijau yang sampai saat ini masih banyak yang beralih fungsi dan untuk menjaga kawawasan hijau pemerintah juga membuat peraturan yang berisi perlindungan serta pemberdayaan petani dalam mengolah kawasan hijau.
\end{abstract}

Kata Kunci: Pengendalian Alih Fungsi; Kawasan Hijau; Lahan Pertanian

\begin{abstract}
Indonesia is a country consisting of several islands with unmatched natural beauty. One of the natural charms of Indonesia is the green area, namely rice fields. A place favored by tourists to capture photos of those who are amazed by the charm of rice fields, but it is increasingly being eroded by the era where rice fields are now changing their function from green areas to factory, housing, shops and supermarkets. It is the desire of every individual who wants to be more successful every day but forgets the importance of green area, so the government sets regulations restricting someone to change the function of rice fields, and sanctions for someone who deliberately violates government regulations. This study aims to explain the regulation of the conversion of land for sustainable food agriculture and explain the government's efforts to control the conversion of land for sustainable food agriculture. This research uses normative legal research which is literature law which refers to the legal norms contained in the legislation with a statutory approach. Data sources are primary and secondary legal data. The results show that government regulations cannot be realized evenly without awareness from the community itself, jointly implementing an orderly attitude of law that allows the government to reorganize green areas, which up to now are still changing functions and to protect the government's green area as well formulate regulations containing the protection and empowerment of farmers in cultivating green areas.
\end{abstract}

Keywords: Function Transfer Control; Green Area; Agricultural land

\section{PENDAHULUAN}

Manusia mempunyai tanggung jawab untuk melestarikan alam yang terdiri dari kawsan hijau dan kawasan perairan. Kawsan hijau yaitu sawah merupakan kawasan yang sampai saat ini masih menjadi daya tarik tersendiri bagi wisatawan yang berkunjung, mereka mengabadikan kenangan menggunakan sawah sebagai latar belakangnya (Soedjono, 1998).

Saat ini diketahui bahwa semakin hari semakin naik kawasan hijau yang dijadikan lahan untuk kawasan perkantoran dan toko swalayan. Hal ini membuat petani gigit jari dan semakin sulit untuk meningkatkan kebutuhan pangan. Melihat perkembangan peralihan sawah yang kian hari kian meningkat akhirnya pemerintah menetapkan peraturan tentang agraria, aturan agraria berisi hak pemerintah menguasai sumber daya alam artinya pemerintah beserta komponen lain berhak 
mengelola untuk menjadikan alam semakin tertata bukan menguasai berarti melarang pemilik lahan sawah untuk mempergunakan sawah namun membatasi peralihan fungsi lahan sawah demi terciptanya kawasan hijau yang menarik perhatian banyak wisatawan untuk berkunjung (Budi Harsono, 1997).

Negara Indonesia yang kaya akan lahan pertanian menjadi daya tarik tersendiri namun besarnya volume masyarakat dengan pola pikir dan keinginan berbeda-beda membuat alih fungsi lahan sangat mudah terjadi di Indonesia. Untuk menunjang pertambahan penduduk maka lahan produktif akan dijadikan perumahan. Kawasan pertanian di Indonesia sampai saat ini masih banyak masyarakat yang menjadikan hasil penjualan panen sawah menjadi penghasilan tetap mereka. Namun seiring dengan berjalannya waktu, banyak lahan sawah mulai berkurang akibat para petani yang tidak mampu untk mempertahankan lahan sawah miliknya. Penyebab jumlah lahan pertanian semakin berkurang akibat pertumbuhan penduduk yang semakin pesat, kebutuhan pangan meningkat dan banyaknya pembangunan, sehingga jumlah produksi pertanian semakin berkurang.

Perlindungan terhadap lahan pertanian terutama lahan pertanian pangan berkelanjutan sudah merupakan kebijakan pemerintah untuk membuat berbagai kebijakan baik dalam bentuk undangundang maupun peraturan-peraturan lainnya. Namun apabila upaya pengendalian lahan pertanian pangan tersebut tidak mendapat dukungan yang memadai atau tidak terintegrasi ke dalam pembangunan sektor pertanian yang terpadu maka upaya tersebut tidak akan berhasil. Penelitian sebelumnya mengungkapkan bahwa Penyalah gunaan lahan sawah akan membawa dampak yang serius terhadap ketahanan pangan bangsa karena hampir semua penduduk Indonesia mengkonsumsi beras sebagai makanan pokok (Widayati, 2015). Tujuan Pemerintah menetapkan Undang-Undang Nomor 41 Tahun 2009 tentang Perlindungan Lahan Pertanian Pangan Berkelanjutan untuk mengendalikan alih fungsi lahan pertanian sehingga menghindari kepunahan kawasan hujau (Janti et al., 2016). Menurut Akadir et al., (2019) tugas dan tanggung jawab yuridis Pemerintah dalam perlindungan alih fungsi lahan pertanian pangan berkelanjutan kepada masyarakat masih belum terlaksana dengan baik sesuai yang diharapkan masyarakat.

Jika praktek alih fungsi terhadap lahan pertanian ini tidak terkendali, maka ketahanan pangan akan terganggu. Adanya alih fungsi lahan tersebut akan mempengaruhi produksi pertanian sehingga untuk memenuhi kebutuhan pangan rakyat Indonesia harus mengimpor dari luar. Penelitian ini bertujuan menjelaskan pengaturan alih fungsi lahan pertanian pangan berkelanjutan dan menjelaskan upaya pemerintah dalam pengendalian alih fungsi lahan pertanian pangan berkelanjutan

\section{METODE PENELITIAN}

Penelitian ini menggunakan Penelitian hukum normatif yaitu hukum kepustakaan yang mengacu pada norma hukum yang terdapat dalam peraturan perundang-undangan (Waluyo, 2002). Karena penelitian ini menelaah tentang peraturan yang berkaitan dengan perundang-undangan maka pendekatan yang digunakan adalah pendekatan perundangan-undangan yaitu melakukan suatu penelitian dengan berpatokan pada undang-undang sebagai pedoman dalam mengalisis persolan yang sedang diteliti tanpa keluar dari zona hukum positif. Menggunakan metode normatif dan kualitatis dimana dalam pengerjaannya peneliti menelaah isu hukum dengan didasari peraturanperaturan hukum Agraria di Indonesia serta mengaitkan hukum positif yang berlaku (Ahmad, 2008).

\section{HASIL DAN PEMBAHASAN}

\section{Pengaturan Alih Fungsi Lahan Pertanian Pangan Berkelanjutan}

Sektor pertanian merupakan salah satu sumber penghasilan pokok sandang dan pangan Negara. Dari pertanian masyarakat dapat menikmati makanan sehat seperti sayur-sayuran, ubi dan beras yang merupakan makanan pokok. Apabila lahan sawah beralih fungsi maka sawah yang merupakan sumber penghasilan sandang pangan akan punah dan Indonesia selalu mengimpor sumber makanan pokok dari negara tetangga yang menimbulkan besarnya hutang negara (Arsyad \& Rustiadi, 2008).

Pemerintah tidak tinggal diam mengetahui maraknya kasus peralihan lahan pertanian yang terjadi, pemerintah mengambil sikap dengan mengeluarkan aturan yang bertujuan melindungi mata pencarian petani sebagai sumber bahan pangan negara. Aturan tersebut dapat membuat area persawahan menjadi kawasan hijau berkelanjutan yang artinya area sawah menjadi daerah sentral 
atau bila ingin beralih fungsi maka melapor pada pemerintah dengan membawa surat kepemilikan asli. Jika tidak disetujui kedepan tidak boleh ada permintaan alih fungsi sawah di area tersebut. Aturan tersebut diharap dapat menekan ego masyarakat yang ingin alih fungsi sawah mereka, disamping membuat kesulitan bahan pangan juga menurunkan minat wisatawan berkunjung ke Indonesia karena sudah tidak ada objek wisata mereka yaitu area persawahan. Area hijau berkesinambungan dibuat pemerintah dan diberlakukan rata diseluruh wilayah tanpa terkecuali.

Kebijakan pemerintah memberlakukan area hijau berkelanjutan guna mengurangi kegiatan impor bahan pokok yang membuat hutang negara membengkak dan kebijakan ini berlaku seterusnya dan akan diperbaharui setiap tahunnya mengikuti aturan serta perkembangan jaman dikemudian hari. Dengan demikian maka minat orang-orang yang mementingkan ego sendiri menjadi tertahan dengan diberlakukannya aturan pemerintah tentang area hujau berkelanjutan dan barang siapa yang melanggar aturan pemerintah mendapat sanki.

Area hijau persawahan yang terdata sebagai lahan berkelanjutan dapat terus memproduksi bahan pangan yang nantinya dijual kepada masyarakat sekitar. Area sawah yang tidak termasuk area hijau berkelanjutkan dapat dialih fungsikan dengan seizin pemerintah dan harus mengajukan permohonan alih fungsi. Namun bila pemerintah tidak setuju maka alih fungsi area persawahan dapat dibatalkan. Demi menunjang area hijau berkelanjutan dan mengantisipasi pola pikir masyarakat yang secara diam-diam mengalih fungsikan lahan mereka pemerintah membuat aturan baru tentang perlindungan area lahan hijau berkelanjutan. Tujuannya lebih menekan niat masyarkat merubah sawah menjadi bangunan demi menjaga ekosistem dan terdapat sanksi bagi mereka yang tanpa sepengetahuan pemerintah mengalih fungsikan lahan sawah.

Pemerintah pusat meneruskan aturan tersebut kepada pemerintah daerah untuk segera merealisasikan aturan tentang larangan alih fungsi sawah. Pemerintah daerah menawarkan kepada petani lahan mereka dijadikan area sawah berkelanjutan. Bagi petani yang bersedia lahan mereka dijadikan area berkelanjutan maka akan diberikan tunjangan dan harus giat memproduksi bahan pangan, menjaga kebersihan area sawah, serta meningkatkan kesuburan lahan. Dengan demikian masyarakat yang berprofesi sebagai petani semakin semangat mengelola lahan mereka, sisi positif lainnya para petani memiliki penghasilan tetap ditambah hasil panen sawah yang diperjual belikan pada masyarakat sebagai bahan pokok sehari-hari. Kedepan semakin banyak yang memikirkan kondisi lingkungan, semakin banyak yang peduli keseimbangan alam dan efek bagi pariwisata jika memaksakan alih fungsi area sawah.

\section{Upaya Pemerintah dalam Pengendalian Alih Fungsi Lahan Pertanian Pangan Berkelanjutan}

Beberapa langkah dapat diambil pemerintah demi menekan niat masyarakat untuk alih lahan sawah dan membuka pola pikir masyarakat tentang pentingnya sawah sebagai sumber penghasilan pangan demi mengurangi hutang negara terkait impor bahan pangan. Adapun upaya yang dapat dilakukan diantaranya:

1. Pemerintah pusat beserta jajarannya meneruskan aturan area sawah berkelanjutan kepada pemerintah daerah dan mensosialisasinya kepada masyarakat desa yang memiliki lahan sawah agar memikirkan lagi niat mereka untuk alih fungsi area persawahan serta aturan area lahan sawah berkesinambungan merupakan aturan yang bersifat mengikat dan memiliki sanksi bagi siapa saja yang melanggar aturan tersebut

2. Kebijakan pemberian insentif terhadap petani yang tetap mempertahankan lahan produktifnya. Bagi petani yang bersedia lahan mereka dipergunakan untuk area sawah berkesinambungan akan diberikan tunjangan dengan syarat selalu menghasilkan panen yang dapat diperjualbelikan nantinya.

Peraturan ini mengatur bentuk insentif yang diberikan dalam pengelolaan LP2B dengan cukup rinci. Insentif tersebut diberikan oleh pemerintah pusat Provinsi maupun daerah kepada petani. Secara umum, bentuk insentif yang diberikan hampir sama dari pusat sampai kabupaten yaitu dalam bentuk diantaranya seperti: mengembangkan benih unggul, pengembangan infrastruktur pertanian, pembiayaan penelitian, kemudahan untuk mengakses informasi, meningkatkan teknologi penyediaan sarana produksi, jaminan penerbitan sertifikat hak atas tanah, keringanan pajak bumi dan bangunan hingga pemberian penghargaan kepada petani berprestasi.

Dalam hal pengendalian alih fungsi lahan pertanian pangan berkelanjutan partisipasi masyarakat sangat diperlukan. Konsep partisipasi masyarakat berkaitan dengan konsep keterbukaan 
artinya tanpa adanya keterbukaan pemerintahan, masyarakat tidak mungkin dapat ikut serta dalam kegiatan-kegiatan pemerintahan (Philipus M. Hadjon, 1997). Beberapa hasil penelitian yang dilakukan oleh Pusat Penelitian Sosial Ekonomi Pertanian, dapat dikatakan bahwa Salah satu hal dari kasus alih fungsi lahan yang seharusnya diwaspadai adalah yang sifatnya tidak tentu dan berdimensi individu untuk berbagai keperluan seperti perumahan dan fasilitas lainnya (Sumaryanto et al 2002 31). Pemerintah secara sengaja memberlakukan aturan tentang larangn alih fungsi lahan demi menghentikan pembangunan yang semakin hari semakin bertambah yang membuat banyak menimbun polusi udara dari hasil kelola usaha masyarakat. Selain pemerintah yang gencar dalam usahanya mempertahankan area hijau di Indonesia, masyarakat sendiri harus sadar betapa pentingnya area persawahan dalam keberlangsungan hidup, hasil panen berlimpah yang menjadi makanan pokok sehari-hari berasal dari sawah yang setiap hari ada saja yang menjual demi mencukupi kebutuhan ekonomi. Keadaan yang tidak bisa disalahkan juga kenapa orang sampai ingin mengalih fungsikan lahan mereka.

Dengan adanya partisipasi masyarakat mentaati dan mematuhi aturan yang telah dibuat pemerintah sebagai bagian dari orang yang memutus rantai alih lahan sawah dan ikut bertanggung jawab, khususnya bagi para petani, bukan sebagai obyek dari kebijakan perlindungan lahan pertanian. Oleh karenanya, partisipasi masyarakat sangat diperlukan untuk tidak mengalih fungsikan lahan pertanian pangan dari masyarakat khususnya petani, serta komitmen pemerintah untuk menegakkan aturan dalam mengendalikan alih fungsi lahan. Dengan demikian, ketersediaan lahan pertanian pangan di suatu daerah akan terjamin, sebagai bentuk keberhasilan dari pelaksanaan UUPLP2B secara kuantitatif dalam melindungi lahan pertanian pangan secara terus menerus dari ancaman alih fungsi lahan guna menyokong kebutuhan pangan masyarakat.

\section{SIMPULAN}

\section{Simpulan}

Berdasarkan hasil analisis data, hasil penelitian menunjukkan bahwa pergerakan masyarakat dalam upayanya mengalih fungsikan area persawahan semakim menjadi-jadi dan banyak diantara masyarakat tanpa pikir panjang membuat area sawah mereka menjadi area perkantoran dan sejenisnya yang membuat semakin terkikisnya lahan hijau yang ada di Indonesia. Mengetahui hal ini maka pemerintah beserta jajarannya membuat aturan yang membatasi setiap warga mengalih fungsikan lahan persawahan sehingga pemerintah membuat strategi dinamakan area hijau dibuat berkelanjutan. Bagi masyarakat yang dengan sengaja tidak mematuhi aturan pemerintah dan masih saja mengalih fungsikan area sawah maka akan diberikan sanksi bersifat tegas, yang kedua Pemerintah sudah memiliki acuan untuk pemberian insentif bagi petani yang mempertahankan lahan sawahnya. Pemberian insentif tersebut dilaksanakan sesuai Peraturan Pemerintah Nomor 12 tahun 2012 tentang Insentif Perlindungan Lahan Pertanian Pangan Berkelanjutan yang mengatur dengan cukup rinci bentuk insentif yang diberikan dalam pengelolaan lahan pertanian pangan berkelanjutan yang kemudian diwujudkan dengan suatu strategi yang menekankan pada partisipasi masyarakat sebagai pengendalian alternatif

\section{Saran}

Berdasrkan hasil penelitian ini, maka peneliti memberi saran yaitu Sebaiknya pemerintah daerah melakukan evaluasi menyeluruh terhadap pelaksanaan Lahan Pertanian Pangan Berkelanjutan dengan melakukan penyuluhan mengenai peran dari Undang-Undang Nomor 19 Tahun 2013 tentang Perlindungan dan Pemberdayaan Petani sehingga petani di Indonesia mengetahui payung hukum yang melindunginya. Menjalin kerjasama antara petani pemerintah dan masyarakat untuk membangun pertanian yang lebih maju agar dapat memulihkan perekonomian nasional, yang kedua Perlu dibuatkan rumusan penentuan pemberian insentif dan disinsentif yang akan diterima petani pada saat penetapannya untuk meningkatkan pemberdayaan pendapatan dan kesejahteraan bagi petani. Pemberian tunjangan kepada petani jangan sampai menunggak karena dapat mempengaruhi hasil panen mereka ditambah pemikiran petani selaku orang desa tidak begitu cerdas, akan sangat gampang terpengaruh yang dapat merugikan negara. 


\section{DAFTAR PUSTAKA}

Ahmad, B. (2008). Metode Penelitian Hukum. Pustakasetia.

Akadir, lisa novita, Ismail, I., \& Sulaiman. (2019). Tanggung Jawab Pemerintah Daerah Dalam Perlindungan Alih Fungsi Lahan Pertanian Pangan Berkelanjutan. Jurnal IUS Kajian Hukum Dan Keadilan, 7(3), 477494.

Arsyad, S., \& Rustiadi, E. (2008). Manajemen Sumber Daya Lahan dan Usaha Pertanian Berkelanjutan. Crestpent Press dan Yayasan Obor.

Budi Harsono. (1997). Hukum Agraria Indonesia Sejarah Pembentukan Undang-Undang Pokok Agraria, Isi Dan Pelaksanaanya. Djambatan.

Janti, G. I., Martono, E., \& Subejo. (2016). Perlindungan Lahan Pertanian Pangan Berkelanjutan Guna Memperkokoh Ketahanan Pangan Wilayah (Studi di Kabupaten Bantul, Daerah Istimewa Yogyakarta). Jurnal Ketahanan Nasional, 22(1), 1-21.

Soedjono, A. (1998). Prosedur Pendaftaran Tanah Tentang Hak Milik Sewa Guna dan Hak Guna Bangunan. Rineka Cipta.

Waluyo, B. (2002). Penelitian Hukum Praktek. Sinar Grafika.

Widayati, W. (2015). Kebijakan Perlindungan Lahan Pertanian Pangan Berkelanjutan di Kabupaten Demak. Jurnal Ilmiah Ilmu Pemerintahan, 1(1), 5-11. 